\title{
Role of the $T$ and $B$ lymphocytes in pathogenesis of autoimmune thyroid diseases
}

\author{
Marta Rydzewska, Michał Jaromin, Izabela Elżbieta Pasierowska, Karlina Stożek and Artur Bossowski*
}

\begin{abstract}
Autoimmune thyroid disorders (AITD) broadly include Graves' disease and Hashimoto's thyroiditis which are the most common causes of thyroid gland dysfunctions. These disorders develop due to complex interactions between environmental and genetic factors and are characterized by reactivity to self-thyroid antigens due to autoreactive lymphocytes escaping tolerance. Both cell-mediated and humoral responses lead to tissue injury in autoimmune thyroid disease. The differentiation of CD4+ cells in the specific setting of immune mediators (for example cytokines, chemokines) results in differentiation of various T cell subsets. T cell identification has shown a mixed pattern of cytokine production indicating that both subtypes of T helper, Th1 and Th2, responses are involved in all types of AITD. Furthermore, recent studies described T cell subtypes Th17 and Treg which also play an essential role in pathogenesis of AITD. This review will focus on the role of the T regulatory (Treg) and T helper (Th) (especially Th17) lymphocytes, and also of B lymphocytes in AITD pathogenesis. However, we have much more to learn about cellular mechanisms and interactions in AITD before we can develop complete understanding of AITD pathophysiology.
\end{abstract}

Keywords: Autoimmune thyroid diseases, T helper, T regulatory, Graves' disease, Hashimoto's thyroiditis

\section{Introduction}

Graves' disease (GD) and Hashimoto thyroiditis (HT) are classified as autoimmune thyroid disorders (AITD) characterized by the breakdown of self-tolerance to thyroid antigens resulting in circulation of antibodies and lymphocyte infiltration [1]. There is a growing trend for the prevalence of Hashimoto's disease and it is estimated at approximately $5-10 \%[2,3]$. Women are diagnosed with it five to ten times more often than men and its frequency increases with the age (the highest number of cases is observed between 45 and 65) [3]. In pediatric population, the most common age at presentation is adolescence' yet, HT may develop at any time, rarely even in infants $[4,5]$. In case of GD, meta-analyses of different studies have estimated the general frequency of the disease to be about 1\% [6]. However, Graves' disease is four to five times more common in women than in men [7].

\footnotetext{
* Correspondence: abossowski@hotmail.com

Department of Pediatrics, Endocrinology and Diabetes with a Cardiology Unit, Medical University of Bialystok, ul. Waszyngtona 17, 15-274 Białystok, Poland
}

The pathogenesis of HT is basically the result of cellmediated autoimmune, whereas GD results from humoral autoimmunity [8, 9]. However, as in other autoimmune disorders, in AITD, humoral and cellular immune mechanisms are closely connected and crosslinked [10]. Moreover, in both diseases, the thyroid cell itself takes part in the intrathyroidal immune process. Classically, HT is considered to be a Th1-mediated disease' yet, this classification has altered due to the description of new Th cell subsets including Th17 cells [11]. In accordance with the newest research findings, uncontrolled Th17 cell responses have been involved in different types of autoimmune diseases, which were previously supposed to be Th1-dependent diseases [12]. In $\mathrm{HT}$, as a consequence, chronic inflammatory cell infiltrates into the thyroid gland, which includes predominantly thyroid-specific B and T cells. In result, goiter may initially be caused [13]. Subsequently, hypothyroidism, the characteristic hallmark of thyroiditis, can develop when sufficient numbers of follicular cells responsible for the production and secretion of thyroid hormones thyroxine (T4) and triiodothyronine (T3) are destroyed 
[14]. It is now well established that GD, B, and $T$ lymphocyte-mediated autoimmunity are known to be directed against four well-known thyroid antigens: thyroglobulin (Tg), thyroid peroxidase (TPO), sodium-iodide symporter (NIS) and the thyrotropin receptor (TSH-R) $[15,16]$. However, the THS-R itself is the main autoantigen of GD [17]. The circulating agonist autoantibodies against the TSH-R (TRAb), which bind to and activate the receptor, they, thereby, chronically stimulate thyroid hormone synthesis and secretion (causing hyperthyroidism) as well as thyroid hyperplasia and (causing a diffuse goiter) [18]. Furthermore, TRAb, particularly in children, strongly stimulate thyroid function and have prognostic significance, probably as costimulatory molecules $[19,20]$. Thyroid-associated ophthalmopathy occurs in around $25 \%$ of cases and is the most common extrathyroidal manifestation of GD [21, 22]. Furthermore, both the humoral and cellular immune actions seem to be present in its pathogenesis [22].

The majority of researchers share the opinion that AITD are multifactorial diseases, caused by a complex interplay of genetic, hormonal, and environmental influences that provoke the development of inappropriate immune responses against thyroid on multiple levels and the initiation of a long-standing autoimmune reaction [23-25]. This review will focus on the role of the $\mathrm{T}$ regulatory (Treg) and $\mathrm{T}$ helper (Th) (especially Th17) lymphocytes, and also of B lymphocytes in AITD pathogenesis. However, we have much more to learn about cellular mechanisms and interactions in AITD before we can develop complete understanding of AITD pathophysiology.

\section{T lymphocytes}

$\mathrm{T}$ lymphocytes originate from precursor stem cells in fetal liver and bone marrow and differentiate into mature cell types after migration to the thymus [26]. T lymphocytes may be categorized based on their distinct function into cytotoxic $\mathrm{T}$ lymphocytes (expressing the surface protein cluster of differentation (CD) 8 and responsible mainly for immune defence against intracellular pathogens and for tumour surveillance) and helper $\mathrm{T}$ lymphocytes (expressing the surface protein CD4) [27]. In this review, we focus on CD $4+$ cells. Helper T cells (naïve $\mathrm{CD} 4+\mathrm{T}$ lymphocytes) are triggered when they are presented with peptide antigens by MHC (major histocompatibility complex) class II molecules, which are expressed on the professional antigen-presenting cells (APCs) surface. Both are necessary for production of an adequate immune response [28]. $\mathrm{T}$ cells have on their surface $\mathrm{T}$ cell antigen receptors (TCR) responsible for recognition of an antigen/major histocompatibility complex (HLA complex), immunological accessory molecules identifying HLA determinants, and adhesion molecules recognizing their counterpart ligands on APCs [29, 30].

Once activated, helper (CD4+) T cells can be subdivided into at least three main functional subtypes according to releasing cytokines, the Th1 subset (mainly involved in cell-mediated tissue-damaging reaction), the Th2 subset (driving B cells to produce antibodies in the humoral immune response), and Th17 cells (playing a role in immune responses to infectious agents and maintenance of autoimmune diseases) [31, 32]. Th 1 cells produce tumor necrosis factor- $\beta$ (TNF- $\beta$ ), interferon gamma (IFN- $\gamma$ ), and interleukin (IL) 2,; Th 2 cells secrete mainly IL-4, IL-5, IL-6, and IL-13, and Th17 secrete IL17 [27, 28, 33] (Fig. 1). Moreover, some CD4+ T cells produce both Th1 and Th2 cytokines and have been termed Th0 [34]. Determination of Th subtype is activated during an immune response, which depends on the type of antigen and its concentration, the nature of the initial antigen-presenting cell, and, probably, on illdefined genetic and environmental influences [35]. We recognize also set of $\mathrm{T}$ cells that can suppress these inflammatory responses, described as regulatory $\mathrm{T}$ cells (T regs) [32, 36] (Fig. 1).

The particular factors beginning thyroid autoimmunity are not well known, but many potential influences have been described. Development of autoimmunity is, probably, as mentioned, a process including both genetic and environmental effects [23-25]. Immunologic self-tolerance is induced during the perinatal period, when immature lymphocytes in the thymus are exposed to selfantigens $[37,38]$. At this crucial moment, clonal deletion or induced anergy of autoreactive $\mathrm{T}$ cells determines self-tolerance to autoantigens. However, these mechanisms are never ideal and some autoreactive cells may be normally present in their circulation [39]. As we described above, AITD arise from a breakdown of self-tolerance to thyroid antigens and this process might be induced by excessive exposure to thyroid antigens, a modified self-antigen, exposure to environmental antigens that mimic a self-antigen, polyclonal immune activation, or idiotypecross-reaction of self-antigens [40].

\section{Th1 and Th2 lymphocytes}

The relationship between GD and HT has been discussed for many years. The familial association with GD and the fact that it may sometimes develop into HT (and vice versa) seem to signify that the two disorders are closely related pathophysiologically, although not functionally [41, 42]. Mixed mRNA (messenger ribonucleic acid) pattern of cytokine secretion revealed that both the Th1 and Th2 subtypes of the helper T cell responses are involved in both Graves' disease and Hashimoto's thyroiditis [43]. In HT Th1, lymphocytes activate a strong lymphocyte inflammatory infiltrate 


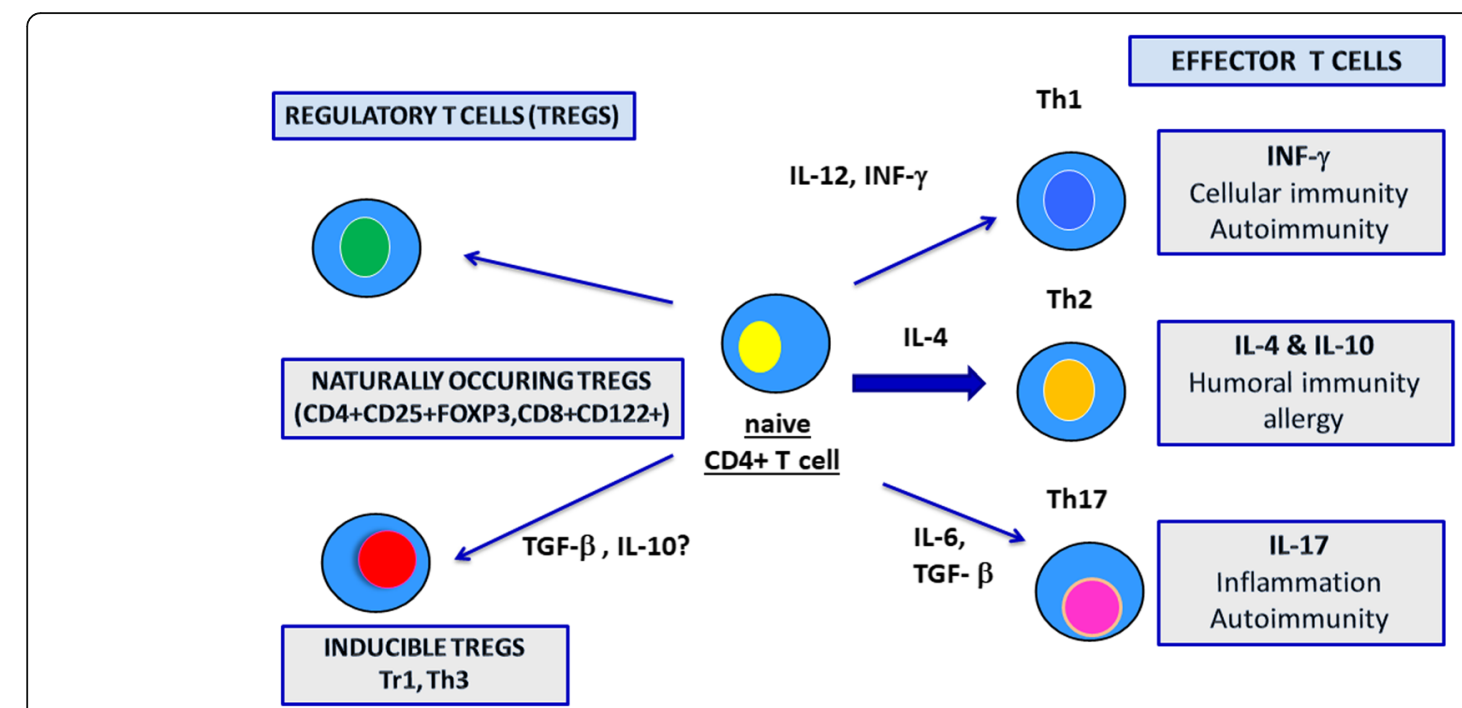

Fig. 1 The differentiation of CD4+ cells into specific T cell subsets. Cytokines play crucial roles in determining Th cell differentiation and the combination of cytokines is required for the differentiation of each subset

of the thyroid, which causes subsequent thyroiditis and thyroid gland damage. This is caused by activation of cytotoxic lymphocytes and macrophages, which directly affect thyroid tissue by destroying thyroid follicular cells [44]. Furthermore, in HT, thyroid follicular cells are induced to express functional Fas receptor and also Fas ligand (two molecules involved in the regulation of programmed cell death) by cytokine stimulation from APCs and Th1 cells (mainly interleukin-1). This mechanism may cause selfapoptosis [45]. On the other hand, Th2 induce an excessive stimulation and production of $\mathrm{B}$ cells and plasmatic cells, which produce antibodies against thyroid antigens leading also to thyroiditis [46]. In fact, although HT is characterized by cell-driven destruction to thyroid cells, autoantibodies to TPO and $\mathrm{Tg}$ are also a crucial component in its pathogenesis [47].

The misfunction of Th1subtype of lymphocytes has also been reported in GD, which contradicts, as we mentioned, the traditional view that HT was caused by Th1mediated cellular immune mechanisms and GD by humoral Th2-mediated mechanisms only [42]. Most Graves' patients also have detected in blood tests autoantibodies to TPO and, less frequently, to Tg [48]. Th1 cytokines induce the production of subclass immunoglobulin (Ig) G1, whereas Th2 cytokines drive the generation of subclass IgG4 [49]. Furthermore, the early phase of a humoral immune response generally includes IgG1, whereas presence of antibodies to subclass IgG4 is associated with long-standing immunization, TPO and $\mathrm{Tg}$ autoantibodies may comprise IgG4 as well as IgG1 subclasses, indicating participation of Th2 and Th1 cytokines [50]. Moreover, it was assessed that the stimulating activity of thyrotropin receptor antibodies found mostly in the IgG1 subclass, which is selectively induced by Th 1 cells [51]. It is also worthwhile noting that Th1 cells may also induce antibody production through secretion of IL-10, which, in turn, activates B cells [52]. In case of GD, persistent increased levels of autoantibodies directed against TSHR stimulate the growth and function of thyroid follicular cells, thus, leading to development of goiter and hyperthyroidism [18]. To sum up, IgG1 antibodies (such as Th1-related TSAb) arise early in the immune response, whereas IgG4 antibodies (to TPO and $\mathrm{Tg}$, typically Th2-related) arise after prolonged immune stimulation. These conclusions are consistent with the clinical manifestations of GD and HT [53]. Furthermore, one of the newest research papers described the level of mRNA expression for the genes encoding T-bet and GATA3 (main regulators of the Th1 and Th2 differentiation, respectively) together with Th1 (IFN- $\gamma$ ) and Th2 (IL-4) cytokine mRNA expression in patients with GD. The researchers indicated that in comparison with the control group, T-bet and IFN- $\gamma$ mRNA expression levels were significantly up-regulated in the GD patients, while GATA3 and IL-4 mRNA expression levels were downregulated. Their results showed that a Th1/Th2 imbalance is present in GD, and it may be involved in the pathogenesis of disease [54].

\section{Th17 lymphocytes}

It has been noted, that preferential generation of various Th cell subpopulations also includes conversion to subset called Th17 lymphocytes [55], which were discovered and described for the first time in 2003 [56]. This linage of lymphocytes is characterized by production of cytokines 
from IL-17 family [57], which ultimately contributes to exacerbation of autoimmunologic process $[58,59]$. Moreover, their role in pathogenesis of AITD was confirmed by latter research [60].

Although the dissonant data in a matter of Th17 lymphocytes' differentiation has been published so far, it is suspected to be dependent on simultaneous cooccurrence of few factors. Such factors are activation of intracellular pathway called Signal Transducer and Activators of Transcription-3 (STAT3), presence of cytokines (such as IL-6, IL-Beta and IL-23), and high expression of transcription factor receptor-related orphan receptor $\mathrm{C} 2$ (RORC2) on the cells' surface [61-63]. So called classical or conventional Th17 lymphocytes are specified with production and excretion of IL-17A, IL-17-F, IL-21 and IL-22 [64], which main role is intensifying release of other proinflammatory cytokines like IL-Beta, TNF-Alfa, and chemokines. Their crucial role is stimulation of vessel-related cells (epithelial cells) or connective tissue cells (fibroblasts and macrophages) that are primarily involved in causing tissue damages seen in autoimmune inflammatory conditions. Accordingly, further analyses considering Th17-associated levels of cytokines have been carried out. Thus, it was reported that levels of mentioned cytokines such a IL-21, IL-22 and IL-23 have been considerably raised in patients with AITD, especially in HT [63, 65-69]. Moreover, conventional Th17 under sustained exposure to different cytokines may subsequently differentiate to cells performing varied functions, proclaiming high plasticity of this subpopulation. Thus, under prolonged influence of IL23, they turn into specialized pathogenic cells called Th1-like (non-classic Th1), able to synthesize IFN-gamma and granulocytemacrophage colony-stimulating factor (GMCSF), whereas losing the ability of producing IL-17 [70]. Noted cell type undoubtedly has a very relevant impact on the pathogenesis of molecular damages in course of AITD [71-74].

Concerning pathogenesis of AITD, molecules suspected to regulate functions of Th17 have been detected as follows: leptin (inductor, affecting directly naive $\mathrm{T}$ cells), GITRL (inductor, inhibiting functions of Tregs) [59, 75], and galectins, especially type 9 (inhibitor) [76]. In peripheral blood and thyroid inflammatory environment in patients with AITD, especially HT, higher concentration of Th17 and their excreted cytokines were observed. These patients were characterized by higher transcriptional activity of RORC2 gene, affecting with more intense conversion into Th17 cells invitro [59, 77]. Additionally, higher levels of Th17+ T cells and lower proportion Tregs to Th17 were observed in these patients suffering from Hashimoto $[75,76]$. Considerable impact on progress of AITD have an imbalance between Th17 lymphocytes and Tregs, which seems to be very important in development of the disease $[59,78,79]$. $\mathrm{T}$ regulatory cells are responsible for control of autoimmune process, while Th17 cells support autoimmune activities. The Th17/Treg ratio was remarked significantly higher in patients with HT compared with healthy controls and the correlation between the levels of GITRL and the proportion of Th17 cells was found positive [59]. The described positive correlation may be caused by GITRL inhibiting function towards Tregs (see above). Moreover, in patients suffering from HT, there have been also discovered unusually high levels of Th17 cells and Th-17-associated proinflammatory cytokines [79] both in thyroid tissue and/or in peripheral blood which has been confirmed in subsequent assays [80-82]. Additionally, intensified in-vitro conversion of their T cells to Th17 was observed [66]. Altogether, it is clear that Th17 lymphocytes play a key role in development and progress of AITD $[66,83]$, which makes them plausible potential aims for innovative immunosuppressive treatment. The antagonists of Th17 cells such as anti-IL-23, anti-IL-17, anti-IL-6R mAbs, chemokine blockers, or STAT3 inhibitors create a promising possibility of application to patients suffering from AITD.

\section{T regulatory (Treg) cells}

Among many diversified types of cells taking part in pathophysiological process of AITD, the unique subtype of $\mathrm{T}$ lymphocytes, namely $\mathrm{T}$ regulatory cells (Tregs), was observed $[32,36]$. Although their potential role in immunosuppressive processes has been already noted primarily by Gershon and Kondo in 1970 [84], which has been confirmed by subsequent scientific assays [85-87] the interest in the field of suppressor $\mathrm{T}$ cells gradually raises and they remain the main subject of various scientific investigations. $\mathrm{T}$ regulatory cells, belonging to $\mathrm{T}$ helper CD3+ CD4+ cells family, are divided into 5 extensive groups basing on expression of different molecules on their surface; thereby, they promote in each specific immunosuppressive such features as $\mathrm{CD} 4+$ $\mathrm{CD} 25+$ FoxP3+ natural (or constitutive) $\mathrm{T}$ regulatory cells (nTregs), CD4+ CD25+ FoxP3+ inducible (or adaptive) $\mathrm{T}$ regulatory cells (iTregs), peripheral (pTregs), $\mathrm{Tr} 1$ type Tregs (IL-10 dependent), Th3 type Tregs (TGF-alfa dependent, LAP+), and CD8+ Tregs [88]. First two subpopulations of Tregs are best known due to numerous scientific assays. In contrast, three recent groups were narrowly investigated and remain another relevant issue to be addressed in patients with AITD [89]. Furthermore, according to report of Cortes et al., new FoxP3+ CD69+ Treg subset, responsible for maintaining tolerance and protection of developing inflammation, was recently discovered. Interestingly, in regard to another assay, their immunosuppressive functions were impaired in large part of patients with AITD. Natural T regulatory cells are believed to be crucial element in maintaining 
peripheral tolerance in vivo through the active suppression of self-reactive T-cell activation and expansion [89-91]. They are identified by high levels of CD25 whose specific constitutional expression is unique for vast majority of these cells and the IL-2 receptor (IL-2R) $[92,93]$. These two molecules are making Tregs easy to be identified by multi-parametric flow cytometry. Secondly, specified subpopulation of Foxp3+ Tregs, called pTregs, can also be developed from naïve $\mathrm{T}$ cells. Indispensable condition for this process is stimulation in presence of cytokines such as TGF-b and IL-2 [94, 95].

Furthermore, basing on past scientific reports, it has been noted that all Treg cells, mostly with expression of FoxP3, contribute to prevention and pathogenesis of autoimmune diseases, including AITD [63, 96, 97]. Mentioned contribution of Tregs was subsequently confirmed by development of AITD in humans that have qualitative or quantitative disturbances of Foxp3 expression [98-101] and lesser concentration or lack of pTregs and tTregs [102, 103]. Considering both tTregs and pTregs, it was observed that they have a tendency to accumulate in inflammated thyroid tissue [97, 103-105], whereas their count in peripheral blood widely varies in patients suffering from AITD. Nevertheless, it is clear that they are dysfunctional and unable perform their immunosuppressive functions in afflicted subjects $[99,102,106]$. Presumably, the reason for that phenomenon might be connected with possible conversion of Tregs to pro-inflammatory cells (mainly Th17and Th1 lymphocytes) [107-109], in the presence of different cytokines in thyroid's inflammatory microenvironment (IL-2/IL-15 and IL-21/IL-23) [110, 111]. Regardless, there is a need of conducting further studies to prove this thesis. Development of AITD also depends on vulnerability of immune-regulatory genes and their final products of transcription, which are located on the surface of $\mathrm{T}$ regulatory cells such as FOXP3, CD25, and CLTA-4 (Fig. 2). These genes and their products are involved in ensuring proper maintenance of peripheral tolerance (FOXP3 and CD25) and establishing an appropriate co-stimulation (CLTA-4). Due to various factors, improper activity of these immune-regulatory genes would potentially lead to a breakdown in immune tolerance and ultimately autoimmunologic disease such as AITD [112]. Forkhead box P3 (FOXP3) is a gene located on chromosome X (Xp11) [113]. T regulatory cells are characterized by an expression of FOXP3, whose involvement in the processes of differentiation, maintenance, and function of Treg cells is essential [99, 114-117]. In humans, disruptions in FOXP3 gene or deficiencies of this molecule lead to the syndrome comprising immune dysregulation, polyendocrinopathy and enteropathy (IPEX) [118-120], which is more common in men. Diverse polymorphisms of FOXP3 gene have been reported to be corresponding with autoimmune thyroiditis (AITD) $[121,122]$. CD25 (the $\alpha$-chain of the IL$2 \mathrm{R}, \mathrm{IL}-2 \mathrm{R} \alpha$ receptor,) primarily intercedes IL-2 signaling, which is essential for providing survival and growth to CD25 + CD4+ Tregs [123]. Thereby, it is potentially possible that some genetic changes in the CD25 gene predispose to development of an immunological process by disarranging Treg function and adequate development of peripheral tolerance.

CTLA-4 (also called CD152) is a transmembrane protein. Upon T cell activation, ligation of CTLA-4 on the surface of Tregs with its ligands (CD80 and CD86) APCs, competing CD28 (protein responsible for costimulatory signals enabling full activation of $\mathrm{T}$ cells), contributes to diminishing of $\mathrm{T}$-cell activation, reduced IL-2 production and the arrest of $\mathrm{T}$ cell cycling, and further activation. Basing on subsequent findings, it has been presumed that CTLA-4 may perform the key role in regulation of central Treg-mediated suppressive mechanism. The presence of CTLA-4 is originally restricted to the surface of $\mathrm{CD} 4+\mathrm{CD} 25+\mathrm{T}$ cells [124-126] in normal mouse models was constructively expressed by CD25+ CD4+ T cells [127-130], also in humans [131]. Additionally, several variants of single nucleotide in CTLA-4 gene have been connected with risk for thyroid autoimmunity, including both Graves' Disease and Hashimoto thyroiditis [112, 132-135]. Secondly, blockade of CTLA-4 with monoclonal antibodies, was not expressed by responder $\mathrm{T}$ cells, but only by natural Tregs, repealing their immunosuppressive abilities [124]. Intimately, analysis of transcription factors' activity such as FOXP3 revealed that they up-regulate CTLA-4 expression by binding to it's gene promoter region [124], which indicates codependency and cooperation of these mechanisms and their importance in Tregs functioning.

More often, Tregs are considered as a plausible candidate for therapeutic aim in patients with AITD. It has been reported in various studies that presented by iTregs (in-vitro indicated Tregs) state of instability (i.e no signs of proliferation, production of effector cytokines such as IL-2, TNF- $\alpha$, IFN $\gamma$, or IL-4 upon stimulation via their TCR), presumably, as a result of worsened stabilization of Foxp3 expression, differs from nTregs. There is a possibility that the differences in epigenetic modifications contribute to this phenomenon in iTregs. This important remarking for the present complicates or unables the utilization of ex vivo-expanded iTregs for adoptive immunotherapy [95, 136]. Therefore, a mechanism, which enables conversion of unstable into stable iTregs in vivo environment, must be discovered. This requirement is crucial for generating cells suitable for treatment application. Notably, a thorough examination of modifications on epigenetic level in the future assays may help in generating iTregs useful for clinical purposes [95]. 


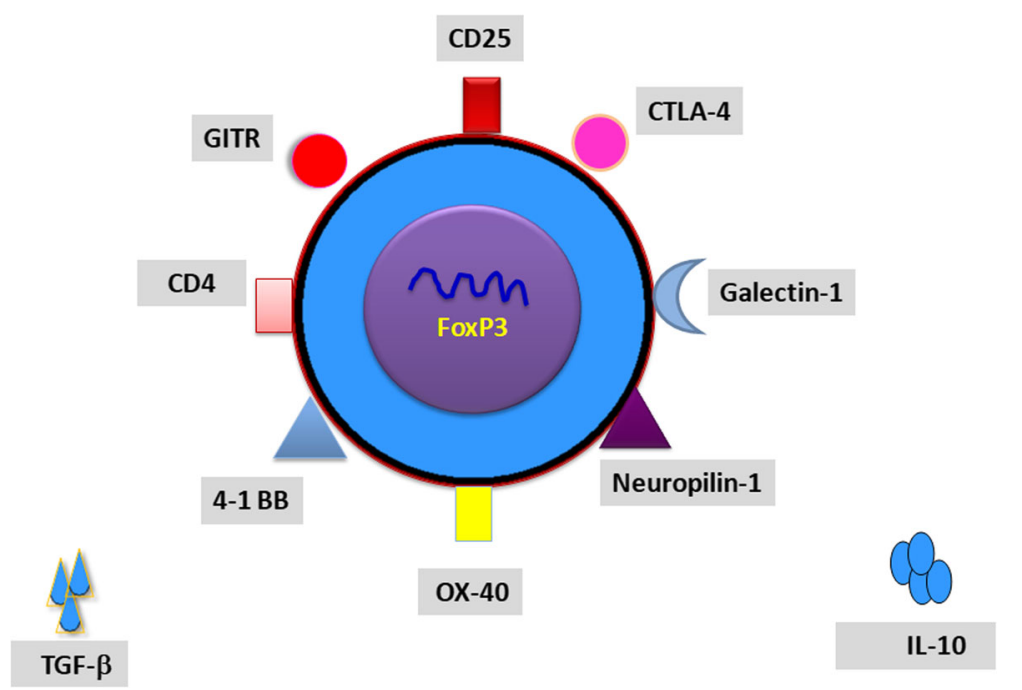

Fig. 2 Schematic representation of Treg cell structure. CD25, cluster of differentiation 25; CD4, cluster of differentiation 4; CTLA-4, cytotoxic T cell antigen 4; OX-40, tumor necrosis factor receptor superfamily, member 4; 4-1 BB, tumor necrosis factor receptor superfamily member 9; GITR, tumor necrosis factor receptor superfamily member 18

\section{B lymphocytes}

B lymphocytes develop from hematopoietic stem cells. Maturation of $\mathrm{B}$ cells takes place in bone marrow, whereas their activation occurs in the secondary lymphoid organs such as lymph nodes and the spleen [137].

$B$ cells represent mainly the humoral immunity. Nevertheless, their role as a cell itself is equally relevant. In practise, they are activated in patients with AITD [3]. In Graves' Disease, B cells play a vital role as they are the source of pathognomonic activating autoantibodies (TRAb) against thyroid-stimulating hormone receptor (TSHR) [10]. TRAb, by binding to the receptor, chronically stimulates it. TSHR is expressed on thyroid follicular cells; thus, the consequence of this chronic stimulation is an increased production and secretion of thyroid hormones $\mathrm{T}_{4}$ and $\mathrm{T}_{3}[43,138]$. Although the role of $\mathrm{B}$ cells in development of Hashimoto's thyroiditis is not as significant as in GD, it should be mentioned that they produce autoantibodies to the thyroglobulin $(\mathrm{Tg})$ and thyroid peroxidase (TPO), which are thyroid selfantigens [10]. Antibody-dependent cell-mediated cytotoxicity is a meaningful factor responsible for apoptosis of thyroid follicular cells in HT.

B cells can also serve as APCs. They have a transmembrane receptor, called BCR (a surface immunoglobulin), which enables them to identify specific antigens, against which they initiate an immune response and synthesize antibodies, and present fragments of these antigens to CD4+ T cells using MHC class II molecules [10, 139]. When the antigen is uncommon, B cells may be the dominant APCs as they have an ability of upconcentration antigens on the cell due to the presence of BCR in the cell membrane [140]. T helper (Th) cells reciprocally support activation of B cells. Particular attention was paid to sequencing of thyroid antibodies and defining B cell epitopes in TSH receptor. This, in turn, could enable further understanding of the pathogenesis of GD, which is a cause of triggering TSHR leading to development of this disease [141]. However, the pace of the autoimmune reaction in AITD is usually slow, which leads its proliferation and differentiation involving many different polyclonal $\mathrm{B}$ and $\mathrm{T}$ cells [10].

$B$ cells exert their activity of antibody synthesis in the thyroid gland. Moreover, intense autoreactive B cell infiltration of the thyroid tissue is observed in patients with AITD [10, 142]. It means that the thyroid may be a major place for thyroid antibody secretion and presents a significant role in promoting persistence of AITD. Additionally, reduced serum concentration of thyroid antibody after surgical or radioiodine thyroid ablation or any other antithyroid drug treatment, is a confirmation of this finding $[10,143]$. There are studies showing that anti-CD20 therapy efficiently depletes B cells in thyroid glands of mice with autoimmune thyroiditis, even though many of thyroid B cells do not express CD20 [144]. Moreover, the fact that the therapy using rituximab, B cell-depleting anti-CD20 antibody, induces clinical improvement in Graves' ophthalmopathy, suggests a crucial role of B cell involvement and provides a base for the development of new therapeutic strategies in patients suffering from AITD [145].

B cells not only participate in proinflamatory reactions. They also play a role in regulation of immune responses. Recent studies identified regulatory B (Breg) cells as specific subsets that have an ability of immune response suppression [143]. They contribute to maintenance of 
peripheral tolerance and inhibition of immune reaction to specific self-antigens, mainly by producing of interleukin-10 (IL-10) but also by transforming growth factor (TGF- $\beta$ ), Fas ligand, and expressing of TNFrelated apoptosis-inducing ligand (TRAIL) $[138,146]$.

There are multiple subsets of IL-10-producing Breg cells that have been described in the studies. In mice, these include marginal-zone (MZ) B cells, transitional 2 marginal-zone precursor (T2-MZP) cells, Tim-1+ B cells, CD $5^{+} \mathrm{CD} 1 \mathrm{~d}^{\text {hi }} \mathrm{B}(\mathrm{B} 10)$ cells, CD138 ${ }^{+}$plasma cells, and plasmablasts [143]. In humans, CD19+ $\mathrm{CD} 24^{\text {hi }} \mathrm{CD} 27^{+}$ and $\mathrm{CD} 19^{+} \mathrm{CD} 24^{\mathrm{hi}} \mathrm{CD} 38^{\mathrm{hi}} \mathrm{CD} 1 \mathrm{~d}^{\mathrm{hi}}$ Breg cells have been described [143]. In latest studies, it has been demonstrated that both in mice and humans, immature B cells, mature $B$ cells, and plasmoblasts have an ability to differentiate into Breg cells [143]. These findings support the conception that the primary condition for Breg cell differentiation is not the expression of a factor specific to Breg cell lineage, but rather the environment in which a B cell is located.

On the ground of a number of data, Breg cells are important in preventing the disease onset and also in suppressing the disease symptoms. Primarily, Breg cells are able to change $\mathrm{T}$ cell differentiation in behalf of a regulatory phenotype [143] (Fig. 3). It is considered that related interactions between Breg cells and $\mathrm{T}$ cells control the induction of $\mathrm{T}$ regulatory (Treg) cells and are important in maintaining Treg cell compartment. There are studies showing that population of Treg cells is reduced in mice with B cell deficiency [143]. According to recent findings, Breg cells have an ability to inhibit Th1 immune responses by the production of IL-10 during chronic infections [143]. Furthermore, they are capable of indirect suppression of Th1 and Th17 cells differentiation by suppressing production of pro-inflammatory cytokines by dendritic cells [140, 143]. Production of

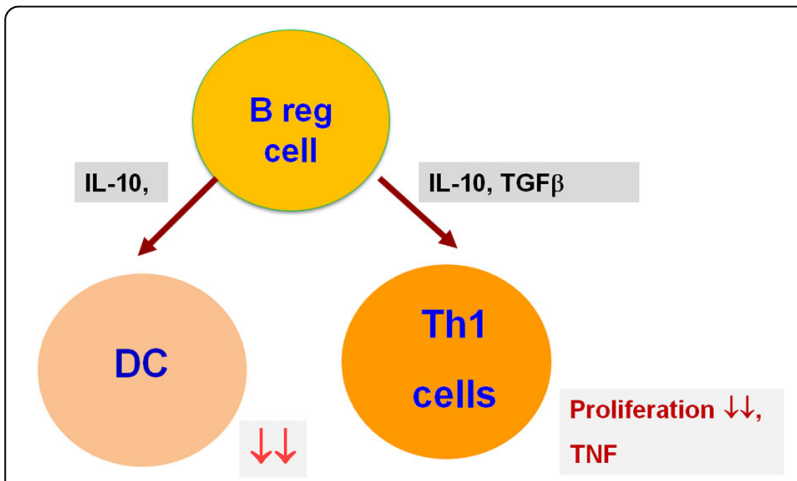

Fig. 3 Schematic representation of Breg cells function. Through the production of IL-10 and TGF- $\beta$ Breg cells can suppress the differentiation of pro-inflammatory lymphocytes and maintain of self-tolerance. DC, dendritic cells, IL-10, interleukin-10; TGFb, transforming growth factor $\beta$; TNF, tumor necrosis factor
TGF- $\beta$ by Breg cells enables them to induce both anergy in CD8+ and apoptosis of CD4+ effector T cells [143]. Microbiota also plays a role in Breg cells generation. In murine studies, population of Breg cells was decreased in mice treated by antibiotics in comparison to untreated individuals [147]. There are also data showing Breg cells dysfunction in human diseases. According to them, chronic exposure of B cells to elevated inflammatory cytokines levels leads to reduction of the functional Breg cells population, which are unable to restore the peripheral tolerance [146, 148]. Moreover, researchers from our university conducted the study which showed a significant decrease of $\mathrm{CD} 19^{+} \mathrm{CD} 24^{\mathrm{hi}} \mathrm{CD} 27^{+} \mathrm{IL}-10^{+}$and CD19+ IL- $10^{+}$B lymphocytes in untreated patients with GD and HT in comparison to the healthy controls. They concluded that the reduction number of Breg cells with expression of $\mathrm{CD} 19^{+} \mathrm{CD} 24^{\mathrm{hi}} \mathrm{CD} 27^{+} \mathrm{IL}-10^{+}$and $\mathrm{CD} 19^{+} \mathrm{IL}-$ $10^{+}(\mathrm{B} 10)$ could be responsible for loses immune tolerance and development of autoimmune process in thyroid disorders [149].

Furthermore, the issue of therapeutic potency of Breg cells is also raised in the studies. According to them, future treatment of AITD should be focused on restoration of immune tolerance. Kristensen in her study [140] suggests some future experiments that could enable better understanding of the pathogenesis of AITD, including measuring the functionality of the IL-10 produced by Breg cells or characterization of the phenotype of these cells in the thyroid tissue in patients with AITD. Clarification of more details of the immune responses regulation by Breg cells could provide a ground for the development of new B cell-mediated therapeutic strategies in patients with AITD $[138,146,147]$.

\section{Acknowledgements}

Not applicable

\section{Funding}

Not applicable

Availability of data and materials

Not applicable

Authors' contributions

All authors were involved in the writing of the manuscript and they read and approved the final manuscript.

Ethics approval and consent to participate Not applicable

Competing interests

The authors declare that they have no competing interests.

\section{Publisher's Note}

Springer Nature remains neutral with regard to jurisdictional claims in published maps and institutional affiliations. 


\section{Received: 13 January 2018 Accepted: 30 January 2018}

\section{Published online: 13 February 2018}

\section{References}

1. Iwatani Y, Watanabe M. Normal mechanisms for self-tolerance. In: Volpe R, editor. Autoimmune Endocrinopathies. Totowa, NJ: Humana Press; 1999. p. 1-31.

2. Hollowell JG, Staehling NW, Flanders WD, Hannon WH, Gunter EW, Spencer CA, Braverman LE, Serum TSH. T(4), and thyroid antibodies in the United States population (1988 to 1994): National Health and nutrition examination survey(NHANES III). J Clin Endocrinol Metab. 2002;87:489-99.

3. Pyzik A, Grywalska E, Matyjaszek-Matuszek B, Rolinski J. Immune disorders in Hashimoto's thyroiditis: what do we know so far? J Immunol Res. 2015; https://doi.org/10.1155/2015/979167.

4. Foley TP Jr, Abbassi V, Copeland KC, Draznin MB. Brief report: hypothyroidism caused by chronic autoimmune thyroiditis in very young infants. N Engl J Med. 1994:330:466-8.

5. Brown RS. Autoimmune thyroiditis in childhood. J Clin Res Pediatr Endocrinol. 2013;5(Suppl 1):45-9. https://doi.org/10.4274/jcrpe.855.

6. Jacobson DL, Gange SJ, Rose NR, Graham NM. Epidemiology and estimated population burden of selected autoimmune diseases in the United States. Clin Immunol Immunopathol. 1997;84:223-43.

7. Carle A, Pedersen IB, Knudsen N, Perrild H, Ovesen L, Rasmussen LB, Laurberg P. Epidemiology of subtypes of hyperthyroidism in Denmark: a population-based study. Eur J Endocrinol. 2011;164:801-9.

8. Antonelli A, Ferrari SM, Corrado A, Di Domenicantonio A, Fallahi P. Autoimmune thyroid disorders. Autoimmun Rev. 2015;14:174-80.

9. Morshed SA, Latif R, Davies TF. Delineating the autoimmune mechanisms in graves' disease. Immunol Res. 2012;54:191-203.

10. Ramos-Leví AM, Marazuela M. Pathogenesis of thyroid auto- immune disease: the role of cellular mechanisms. Endocrinol Nutr. 2016:63:421-9.

11. Nanba T, Watanabe $M$, Inoue $N$, Iwatani $Y$. Increases of the Th1/Th2 cell ratio in severe Hashimoto's disease and in the proportion of Th17 cells in intractable graves' disease. Thyroid. 2009;19:495-501.

12. Bedoya SK, Lam B, Lau K, Larkin, J. Th17 cells in immunity and autoimmunity. Clin Dev Immunol. 2013, https://doi.org/10.1155/2013/986789.

13. Pearce EN, Farwell A, Braverman LE. Thyroiditis. N Engl J Med. 2003;348: 2646-55.

14. Caturegli P, De Remigis A, Rose NR. Hashimoto thyroiditis: clinical and diagnostic criteria. Autoimmun Rev. 2014;13:391-7.

15. Di Cerbo A, Di Paola R, Menzaghi C, De Filippis V, Tahara K, Corda D, Kohn LD. Graves' immunoglobulins activate phospholipase-A2 by recognizing specific epitopes on thyrotropin receptor. J Clin Endocrinol Metab. 1999;84: 3283-92. https://doi.org/10.1210/jcem.84.9.5967.

16. Evans C, Morgenthaler NG, Lee S, Llewellyn DH, Clifton-Bligh R, John R, Lazarus JH, Chatterjee VK, Ludgate M. Development of a luminescent bioassay for thyroid stimulating antibodies. J Clin Endocrinol Metab. 1999:84:374-7.

17. Latif R, Morshed SA, Zaidi M, Davies TF. The thyroid-stimulating hormone receptor: impact of thyroid-stimulating hormone and thyroid-stimulating hormone receptor antibodies on multimerization, cleavage, and signaling. Endocrinol Metab Clin N Am. 2009;38:319-41.

18. Menconi F, Marcocci C, Marinò M. Diagnosis and classification of graves disease. Autoimmun Rev. 2014;13:398-402.

19. Bossowski A, Stasiak-Barmuta A, Urban M. Relationship between CTLA-4 and CD28 molecule expression on T lymphocytes and stimulating and blocking autoantibodies to the TSH-receptor in children with graves' disease. Horm Res. 2005;64:189-97. https://doi.org/10.1159/000088875.

20. Bossowski A, Stasiak-Barmuta A, Urban M, Bossowska A. Analysis of costimulatory molecules OX40/4-1 BB (CD1 34/CD1 37) detection on chosen mononuclear cells in children and adolescents with graves' disease during methimazole therapy. J Pediatr Endocrinol Metab. 2005:18:1365-72

21. Tanda ML, Piantanida E, Liparulo L, Veronesi G, Lai A, Sassi L, et al. Prevalence and natural history of graves' orbitopathy in a large series of patients with newly diagnosed graves' hyperthyroidism seen at a single center. J Clin Endocrinol Metab. 2013:98:1443-9.

22. Shan SJ, Douglas RS. The pathophysiology of thyroid eye disease. J Neuroophthalmol. 2014:34:177-85.

23. Hadj-Kacem H, Rebuffat S, Mnif-Feki M, Belguith-Maalej S, Ayadi H, Peraldi-Roux S. Autoimmune thyroid dis- eases: genetic susceptibility of thyroid-specific genes and thyroid autoantigens contributions. Int J Immunogenet. 2009;36:85-96.
24. Duntas LH. Environmental factors and autoimmune thyroiditis. Nat Clin Pract Endocrinol Metab. 2008:4:454-60.

25. Marino M, Latrofa F, Menconi F, Chiovato L, Vitti P. Role of genetic and nongenetic factors in the etiology of graves' disease. J Endocrinol Investig. 2015:38:283-94

26. Yang Q, Jeremiah Bell J, Bhandoola A. T-cell lineage determination. Immunol Rev. 2010;238:12-22

27. Abbas AK, Murphy KM, Sher A. Functional diversity of helper T lymphocytes. Nature. 1996:383:787-93.

28. Romagnani S. Regulation of the T cell response. Clin Exp Allergy. 2006;36: 1357-66.

29. Kronenberg M, Siu G, Hood LE, Shastri N. The molecular genetics of the Tcell antigen receptor and T- cell antigen recognition. Annu Rev Immunol. 1986:4:529-91.

30. Isakov N. Cell activation and signal initiation. Immunol Today. 1988;9:251-2.

31. Ochs HD, Oukka M, Torgerson TR. TH17 cells and regulatory T cells in primary immunodeficiency diseases. J Allergy Clin Immunol. 2009;123:977-83.

32. Jager A, Kuchroo VK. Effector and regulatory T-cell subsets in autoimmunity and tissue inflammation. Scand J Immunol. 2010;72:173-84.

33. Mosmann TR, Coffman RL. Th1 and Th2 cells: different patterns of lymphokine secretion lead to different functional properties. Ann Rev Immunol. 1989;7:145-73.

34. Hu C, Salgame P. Inability of interleukin-12 to modulate T-helper 0 effectors to T-helper 1 effectors: a possible distinct subset of T cells. Immunology. 1999;97:84-91.

35. Chaplin DD. Overview of the immune response. J Allergy Clin Immunol. 2010;125:3-23.

36. Bettelli E, Carrier Y, Gao W, Korn T, Strom TB, Oukka M, Weiner HL, Kuchroo VK. Reciprocal developmental pathways for the generation of pathogenic effector Th17 and regulatory T cells. Nature. 2006;441:235-8.

37. Nossal GJ, Pike BL. Evidence for the clonal abortion theory of B-lymphocyte tolerance. J Exp Med. 1975;141:904-17.

38. Volpe R, litaka M. Evidence for an antigen-specific defect in suppressor Tlymphocytes in autoimmune thyroid disease. Exp Clin Endocrinol. 1991;97:133-8.

39. Parijs LV, Abbas AK. Homeostasis and self-tolerance in the immune system: turning lymphocytes off. Science. 1998;280:243-8.

40. Bartalena L, Tanda ML, Piantanida A, et al. Environment and thyroid autoimmunity. In: Wiersinga WM, Drexhage HA, Weetman AP, et al., editors. The thyroid and autoimmunity. Stuttgart: Verlag; 2007. p. 60-73.

41. Tamai H, Ohsako N, Takeno K, et al. Changes in thyroid function in euthyroid subjects with family history of graves' disease; a follow up study of 69 patients. J Clin Endocrinol Metab. 1980;51:1123-8.

42. Kraiem Z, Baron E, Kahana L, Sadeh O, Sheinfeld M. Changes in stimulating and blocking TSH receptor antibodies in a patient undergoing three cycles of transition from hypo to hyper-thyroidism and back to hypothyroidism. Clin Endocrinol. 1992:36:211.

43. Ajjan RA, Watson PF, Weetman AP. Cytokines and thyroid function. Adv Neuroimmunol. 1996:6:359-86.

44. Ben-Skowronek I, Szewczyk L, Kulik-Rechberger B, Korobowicz E. The differences in $T$ and $B$ cell subsets in thyroid of children with graves' disease and Hashimoto's thyroiditis. World J Pediatr. 2013;9:245-50.

45. Giordano C, Stassi G, De Maria R, et al. Potential involvement of Fas and its ligand in the pathogenesis of Hashimoto's thyroiditis. Science. 1997;275: 960-3.

46. Berghi NO. Immunological mechanisms implicated in the pathogenesis of chronic Urticaria and Hashimoto thyroiditis. Iran J Allergy Asthma Immunol. 2017;16(4):358-66.

47. Eschler DC, Hasham A, Tomer Y. Cutting edge: the etiology of autoimmune thyroid diseases. Clin Rev Allergy Immunol. 2011;41:190-7.

48. Chardes T, Chapal N, Bresson D, Bes C, Giudicelli V, Lefranc MP, Peraldi-Roux S. The human anti-thyroid peroxidase autoantibody repertoire in graves' and Hashimoto's autoimmune thyroid diseases. Immunogenetics. 2002:54:141-57.

49. Siebenkotten G, Radbruch A. Towards a molecular understanding of immunoglobulin class switching. Ther Immunol. 1995;3:141-6.

50. Rapoport B, McLachlan SM. Graves' hyperthyroidism is antibody-mediated but is predominantly a Th1-type cytokine disease. J Clin Endocrinol Metab. 2014:99:4060-1.

51. Michalek K, Morshed SA, Latif R, Davies TF. TSH receptor autoantibodies. Autoimmun Rev. 2009:9:113-6.

52. Leovey A, Nagy E, Balazs G, Bako G. Lymphocytes resided in the thyroid are the main source of TSH-receptor antibodies in basedow's-graves' disease? Exp Clin Endocrinol. 1992;99:147-50. 
53. McLachlan SM, Rapoport B. Breaking tolerance to thyroid antigens: changing concepts in thyroid autoimmunity. Endocr Rev. 2014;35:59-105.

54. Eshaghkhani Y, Sanati MH, Nakhjavani M, Safari R, Khajavi A, Ataei M, Jadali Z. Disturbed Th1 and Th2 balance in patients with graves' disease. Minerva Endocrinol. 2016;41(1):28-36.

55. Zuniga $L A$, Jain $R$, Haines $C$, Cua DJ. Th17 cell development: from the cradle to the grave. Immunol Rev. 2013;252:78-88.

56. Aggarwal S, Ghilardi N, Xie MH, de Sauvage FJ, Gurney AL. Interleukin-23 promotes a distinct $\mathrm{Cd} 4 \mathrm{Tcell}$ activation state characterized by the production of interleukin-17. J Biol Chem. 2003;278:1910-4.

57. Park H, Li Z, Yang XO, Chang SH, Nurieva R, Wang YH, Wang Y, Hood L, Zhu Z, Tian Q, Dong C. A distinct lineage of CD4 T cells regulates tissue inflammation by producing interleukin 17. Nat Immunol. 2005;6:1133-41.

58. Weaver $C T$, Hatton RD, Mangan PR, et al. IL-17 family cytokines and the expanding diversity of effector T cell lineages. Annu Rev Immunol. 2007;25: $821-52$.

59. Liu Y, Tang X, Tian J, Zhu C, Peng H, Rui K, Wang Y, Mao C, Ma J, Lu L, Xu H, Wang S. Th17/Treg cells imbalance and GITRL profile in patients with Hashimoto's thyroiditis. Int J Mol Sci. 2014;15:21674-86.

60. Korn T, Bettelli E, Oukka M, Kuchroo VK. IL-17 and Thl7 cells. Annu Rev Immunol. 2009;27:485-517.

61. Crome SQ, Wang AY, Kang CY, Levings MK. The role of retinoic acid-related orphan receptor variant 2 and IL-17 in the development and function of human CD4+ T cells. Eur J Immunol. 2009;39:1480-93.

62. Unutmaz D. RORC2: the master of human Th17 cell programming. Eur J Immunol. 2009;39:1452-5.

63. Gonzalez-Amaro R, Marazuela M. T regulatory (Treg) and T helper 17 (Th17) lymphocytes in thyroid autoimmunity. Endocrine. 2016;52:30-8.

64. Wilson NJ, Boniface K, Chan JR, McKenzie BS, Blumenschein WM, Mattson $J D$, et al. Development, cytokine profile and function of human interleukin 17-producing helper T cells. Nat Immunol. 2007:8:950-7.

65. Guo H, Peng D, Yang XG, Wang Y, Xu BC, Ni JS, Meng W, Jiang YF. A higher frequency of circulating $\mathrm{IL}-22(+) \mathrm{CD} 4(+) \mathrm{T}$ cells in Chinese patients with newly diagnosed Hashimoto's thyroiditis. PLoS One. 2014;9(1):e84545. https://doi.org/10.1371/journal.pone.0084545.

66. Figueroa-Vega N, Alfonso-Perez M, Benedicto I, Sanchez-Madrid F, GonzalezAmaro R, Marazuela M. Increased circulating pro-inflammatory cytokines and Th17 lymphocytes in Hashimoto's thyroiditis. J Clin Endocrinol Metab. 2010;95:953-62.

67. Ruggeri RM, Minciullo P, Saitta S, Giovinazzo S, Certo R, Campenni A, Trimarchi F, Gangemi S, Benvenga S. Serum interleukin-22 (IL-22) is increased in the early stage of. Hashimoto's thyroiditis compared to non-autoimmune thyroid disease and healthy controls. Hormones (Athens). 2014;13(3):338-44. https://doi.org/10. 14310/horm.2002.1483.

68. Song RH, Yu ZY, Qin Q, Wang X, Muhali FS, Shi LF, Jiang WJ, Xiao L, Li DF, Zhang JA. Different levels of circulating Th22 cell and its related molecules in graves' disease and Hashimoto's thyroiditis. Int I Clin Exp Pathol. 2014; 7(7):4024-31.

69. Guan LJ, Wang X, Meng S, Shi LF, Jiang WJ, Xiao L, Shi XH, Xu J, Zhang JA. Increased IL-21//L-21R expression and its proinflammatory effects in autoimmune thyroid disease. Cytokine. 2015;72:160-5.

70. Ghoreschi K, Laurence A, Yang XP, Tato CM, McGeachy MJ, Konkel JE, et al. Generation of pathogenic $\mathrm{T}(\mathrm{H}) 17$ cells in the absence of TGF-beta signalling. Nature. 2010;467:967-71.

71. Song $X$, Gao H, Qian Y. Th17 differentiation and their pro-inflammation function. Adv Exp Med Biol. 2014;841:99-151.

72. Basdeo SA, Moran B, Cluxton D, Canavan M, McCormick J, Connolly M, Orr C Mills KH, Veale DJ, Fearon U, Fletcher JM. Polyfunctional, pathogenic CD161+ Th17. Lineage cells are resistant to regulatory T cell-mediated suppression in the context of autoimmunity. J Immunol. 2015;195:528-40.

73. Hatton RD. TGF-beta in Th17 cell development: the truth is out there. Immunity 2011;34:288-90.

74. Feng T, Cao AT, Weaver CT, Elson CO, Cong Y. Interleukin-12 converts Foxp3 ${ }^{+}$regulatory $T$ cells to interferon-gamma-producing Foxp $3^{+} \mathrm{T}$ cells that inhibit colitis. Gastroenterology. 2011;140:2031-43.

75. Wang S, Baidoo SE, Liu Y, Zhu C, Tian J, Ma J, Tong J, Chen J, Tang X, Xu H, Lu L. T cell-derived leptin contributes to increased frequency of T helper type 17 cells in female patients with Hashimoto's thyroiditis. Clin Exp Immunol. 2013;171:63-8.

76. Leskela S, Serrano A, de la Fuente H, Rodriguez-Munoz A, Ramos-Levi A, Sampedro-Nunez M, Sanchez-Madrid F, Gonzalez-Amaro R, Marazuela M.
Graves' disease is associated with a defective expression of the immune regulatory molecule galectin-9 in antigen-presenting dendritic cells. PLoS ONE. 2015; https://doi.org/10.1371/journal.pone.0123938.

77. Qin Q, Liu P, Liu L, Wang R, Yan N, Yang J, Wang X, Pandey M, Zhang JA. The increased but non-predominant expression of Th17- and Th1-specific cytokines in Hashimoto's thyroiditis but not in graves' disease. Braz J Med Biol Res. 2012;45:1202-8.

78. Dieckmann D, Plottner H, Berchtold S, Berger T, Schuler G. Ex vivo isolation and characterization of CD4+CD25+ T cells with regulatory properties from human blood. J Exp Med. 2001;193:1303-10.

79. Bettelli E, Carrier Y, Gao W, Korn T, Strom TB, Oukka M, Weiner HL, Kuchroo VK. Reciprocal developmental pathways for the generation of pathogenic effector TH17 and regulatory T cells. Nature. 2006;441:235-8.

80. Kristensen B, Hegedus L, Madsen HO, et al. Altered balance between selfreactive Thelper (Th)17 cells and Th10 cells and between full-length forkhead box protein 3 (FoxP3) and FoxP3 splice variants in Hashimoto's thyroiditis. Clin Exp Immunol. 2015;180:58-69.

81. Li D, Cai W, Gu R, Zhang Y, Zhang H, Tang K, Xu P, Katirai F, Shi W, Wang L, Huang T, Huang B. Th17 cell plays a role in the pathogenesis of Hashimoto's thyroiditis in patients. Clin Immunol. 2013;149:411-20.

82. Peng $D$, Xu B, Wang $Y$, Guo $H$, Jiang $Y$. A high frequency of circulating Th22 and Th17 cells in patients with new onset graves' disease. PLoS One. 2013; 8(7):e68446. https://doi.org/10.1371/journal.pone.0068446.

83. Zheng L, Ye P, Liu C. The role of the IL-23/L-17 axis in the pathogenesis of graves' disease. Endocr J. 2013;60:591-7.

84. Gershon RK, Kondo K. Cell interactions in the induction of tolerance: the role of thymic lymphocytes. Immunology. 1970;18:723-37.

85. Schmidt A, Oberle N, Krammer PH. Molecular mechanisms of Treg-mediated T cell suppression. Front Immunol. 2012;3:51.

86. Shevach EM. Biological functions of regulatory T cells. Adv Immunol. 2011; 112:137-76.

87. Corthay A. How do regulatory T cells work? Scand J Immunol. 2009;70:326-36.

88. Akdis M, Akdis AC. Immune tolerance. In: Adkinson Jr BSB, Busse BW, Holgate WW, Lemanske Jr ST, O Hehir RE, editors. Middleton's allergy: principle and practice. Philaadelphia: Elsevier Saunders Press; 2014. p. 45-64.

89. Sakaguchi $\mathrm{S}$. Naturally arising CD4+ regulatory t cells for immunologic selftolerance and negative control of immune responses. Annu Rev Immunol. 2004:22:531-62.

90. Klarquist J, Denman CJ, Hernandez C, Wainwright DA, Strickland FM, Overbeck A, et al. Reduced skin homing by functional Treg in vitiligo. Pigment Cell Melanoma Res. 2010;23:276-86.

91. Dwivedi M, Kumar P, Laddha NC, Kemp EH. Induction of regulatory T cells: a role for probiotics and prebiotics to suppress autoimmunity. Autoimmun Rev. 2016;15:379-92.

92. Sawant DV, Vignali DA. Once a Treg, always a Treg? Immunol Rev. 2014;259: 173-91.

93. Sakaguchi S, Wing K, Yamaguchi T. Dynamics of peripheral tolerance and immune regulation mediated by Treg. Eur I Immunol. 2009;39:2331-6.

94. Chen W, Jin W, Hardegen N, Lei KJ, Li L, Marinos N, McGrady G, Wahl SM. Conversion of peripheral CD4+CD25- naive T cells to CD4+CD25+ regulatory $T$ cells by TGF-beta induction of transcription factor Foxp3. J Exp Med. 2003;198: 1875-86.

95. Kanamori M, Nakatsukasa H, Okada M, Lu Q, Yoshimura A. Induced regulatory T cells: their development, stability, and applications. Trends Immunol. 2016;37: 803-11.

96. Marazuela M, Garcia-Lopez MA, Figueroa-Vega N, de la Fuente H, AlvaradoSanchez B, Monsivais-Urenda A, Sanchez-Madrid FR, González-Amaro R. Regulatory T cells in human autoimmune thyroid disease. J Clin Endocrinol Metab. 2006;91:3639-46.

97. Roncarolo MG, Gregori S, Bacchetta R, Battaglia M. Tr1 cells and the counterregulation of immunity: natural mechanisms and therapeutic applications. Curr Top Microbiol Immunol. 2014;380:39-68.

98. Glick $A B$, Wodzinski A, Fu P, Levine AD, Wald DN. Impairment of regulatory T-cell function in autoimmune thyroid disease. Thyroid. 2013;23:871-8.

99. Nakahara M, Nagayama Y, Ichikawa T, Yu L, Eisenbarth GS, Abiru N. The effect of regulatory T-cell depletion on the spectrum of organ-specific autoimmune diseases in nonobese diabetic mice at different ages. Autoimmunity. 2011;44: 504-10.

100. Verginis P, Li HS, Carayanniotis G. Tolerogenic semimature dendritic cells suppress experimental autoimmune thyroiditis by activation of thyroglobulinspecific CD4+CD25+ T cells. J Immunol. 2005;174:7433-9. 
101. Mao C, Wang S, Xiao Y, Xu J, Jiang Q, Jin M, Jiang X, Guo H, Ning G, Zhang Y. Impairment of regulatory capacity of CD4+CD25+ regulatory $T$ cells mediated by dendritic cell polarization and hyperthyroidism in graves' disease. J Immunol. 2011;186:4734-43.

102. Kasprowicz DJ, Smallwood PS, Tyznik AJ, Ziegler SF. Scurfin (FoxP3) controls T-dependent immune responses in vivo through regulation of $\mathrm{CD}^{+} \mathrm{T}$ cell effector function. J Immunol. 2003;171:1216-23.

103. Gambineri E, Torgerson TR, Ochs HD. Immune dysregulation, polyendocrinopathy, enteropathy, and X-linked inheritance (IPEX), a syndrome of systemic autoimmunity caused by mutations of FOXP3, a critical regulator of Tcell homeostasis. Curr Opin Rheumatol. 2003;15:430-5.

104. Munoz-Rodríguez A, Vitales-Noyola M, Ramos-Levi A, Serrano-Somavilla A, González-Amaro R, Marazuela M. Levels of regulatory T cells CD69+NKG2D+ $\mathrm{IL}-10+$ are increased in patients with autoimmune thyroid disorders. Endocrine. 2016;51:478-89.

105. Pan D, Shin YH, Gopalakrishnan G, Hennessey J, De Groot LJ. Regulatory T cells in graves' disease. Clin Endocrinol. 2009;71:587-93.

106. Bossowski A, Moniuszko M, Dabrowska M, Sawicka B, Rusak M, Jeznach M, Wójtowicz J, Bodzenta-Lukaszyk A, Bossowska A. Lower proportions of CD4+ CD25(high) and CD4+FoxP3, but not CD4+CD25+CD127(low) FoxP3+ T cell levels in children with autoimmune thyroid diseases. Autoimmunity. 2013;46:222-30.

107. Miyara M, Ito Y, Sakaguchi S. TREG-cell therapies for autoimmune rheumatic diseases. Nat Rev Rheumatol. 2014;10:543-51.

108. Basu R, Hatton RD, Weaver CT. The Th17 family: flexibility follows function. Immunol Rev. 2013;252:89-103.

109. Lee YK, Mukasa R, Hatton RD, Weaver CT. Developmental plasticity of Th17 and Treg cells. Curr Opin Immunol. 2009;21:274-80.

110. Beriou G, Costantino CM, Ashley CW, Yang L, Kuchroo VK, Baecher-Allan C, Hafler DA. IL-17-producing human peripheral regulatory $T$ cells retain suppressive function. Blood. 2009;113:4240-9.

111. Bossowski A, Moniuszko M, Idźkowska E, Grubczak K, Singh P, Bossowska A, Diana T, Kahaly GJ. Decreased proportions of CD4 + IL17+/CD4 + CD25 + CD127- and CD4 + IL17+/CD4 + CD25 + CD127 - FoxP3+ T cells in children with autoimmune thyroid diseases (.). Autoimmunity. 2016;49(5):320-8. doi: https://doi.org/10.1080/08916934.2016.1183654.

112. Lee HJ, Li CW, Hammerstad SS, Stefan M, Tomer Y. Immunogenetics of autoimmune thyroid diseases: a comprehensive review. J Autoimmun. 2015;64:82-90.

113. Allan SE, Passerini L, Bacchetta R, Crellin N, Dai M, Orban PC, Ziegler SF, Roncarolo MG, Levings MK. The role of 2 FOXP3 isoforms in the generation of human CD4+ Tregs. J Clin Invest. 2005;115:3276-84.

114. Kim JM, Rasmussen JP, Rudensky AY. Regulatory T cells prevent catastrophic autoimmunity throughout the lifespan of mice. Nat Immunol. 2007:8:191-7.

115. Khattri R, Cox T, Yasayko SA, Ramsdell F. An essential role for scurfin in CD4pCD25p T regulatory cells. Nat Immunol. 2003;4:337-42.

116. Fontenot JD, Gavin MA, Rudensky AY. Foxp3 programs the development and function of $\mathrm{CD}^{+} \mathrm{CD}_{2} 5^{+}$regulatory T cells. Nat Immunol. 2003;4: 330-6.

117. Hori S, Nomura T, Sakaguchi S. Control of regulatory T cell development by the transcription factor FOXP3+. Science. 2003;299:1057-61

118. Wildin RS, Ramsdell F, Peake J, Faravelli F, Casanova JL, Buist N, Levy-Lahad E, Mazzella M, Goulet O, Perroni L, et al. X-linked neonatal diabetes mellitus, enteropathy and endocrinopathy syndrome is the human equivalent of mouse scurfy. Nat Genet. 2001;27:18-20.

119. Chatila TA, Blaeser F, Ho N, Lederman HM, Voulgaropoulos C, Helms C, Bowcock AM. JM2, encoding a fork head-related protein, is mutated in Xlinked autoimmunity-allergic disregulation syndrome. J Clin Invest. 2000;106: 75-81.

120. Wildin RS, Freitas A. IPEX and FOXP3: clinical and research perspectives. J Autoimmun. 2005;25:56-62.

121. Ban Y, Tozaki T, Tobe T, Ban Y, Jacobson EM, Concepcion ES, Tomer Y. The regulatory $T$ cell gene FOXP3 and genetic susceptibility to thyroid autoimmunity: an association analysis in Caucasian and Japanese cohorts. J Autoimmun. 2007;28:201-7.

122. Inoue N, Watanabe M, Morita M, Tomizawa R, Akamizu T, Tatsumi K, et al. Association of functional polymorphisms related to the transcriptional level of FOXP3 with prognosis of autoimmune thyroid diseases. Clin Exp Immunol. 2010;162:402-6.

123. Cerosaletti K, Schneider A, Schwedhelm K, Frank I, Tatum M, Wei S, et al. Multiple autoimmune-associated variants confer decreased IL-2R signaling in CD4+ CD25(hi) T cells of type 1 diabetic and multiple sclerosis patients. PLoS One. 2013; https://doi.org/10.1371/journal.pone.0083811.

124. Sakaguchi S, Wing K, Onishi Y, Prieto-Martin P, Yamaguchi T. Regulatory T cells: how do they suppress immune responses? Int Immunol. 2009;21: 1105-11.

125. Grohmann U, Orabona C, Fallarino F, Vacca C, Calcinaro F, Falorni A, et al. CTLA-4-Ig regulates tryptophan catabolism in vivo. Nat Immunol. 2002;3: 1097-101.

126. Suri-Payer $E$, Cantor $H$. Differential cytokine requirements for regulation of autoimmune gastritis and colitis by CD4+CD25+ T cells. J Autoimmun. 2001;16:115-23.

127. Maloy KJ, Powrie JF. Regulatory T cells in the control of immune pathology. Nat Immunol. 2001;2:816-22

128. Marek-Trzonkowska N, Myśliwiec M, Dobyszuk A, Grabowska M, Derkowska I, Juścińska J, Owczuk R, Szadkowska A, Witkowski P, Młynarski W, JaroszChobot P, Bossowski A, Siebert J, Trzonkowski P. Therapy of type 1 diabetes with CD4(+)CD25(high)CD127-regulatory T cells prolongs survival of pancreatic islets - results of one year follow-up. Clin Immunol. 2014;153(1): 23-30. https://doi.org/10.1016/j.clim.2014.03.016.

129. Taams LS, Vukmanovic-Stejic M, Smith J, Dunne PJ, Fletcher JM, Plunkett FJ, Ebeling SB, Lombardi G, Rustin MH, Bijlsma JW, et al. Antigen-specific T cell suppression by human CD4+CD25* regulatory T cells. Eur J Immunol. 2002; 32:1621-30

130. Suri-Payer E, Amar AZ, Thornton AM, Shevach EM. CD4+CD25+ T cells inhibit both the induction and effector function of autoreactive T cells and represent a unique lineage of immunoregulatory cells. J Immunol. 1998;160(3):1212-8.

131. Levings MK, Sangregorio R, Roncarolo MG. Human cd25(+)cd4(+) t regulatory cells suppress naive and memory $T$ cell proliferation and can be expanded in vitro without loss of function. J Exp Med. 2001;193:1295-302

132. Kotsa K, Watson PF, Weetman AP. A CTLA-4 gene polymorphism is associated with both graves disease and autoimmune hypothyroidism. Clin Endocrinol. 1997:46:551-4.

133. Donner H, Rau H, Walfish PG, Braun J, Siegmund T, Finke R, Herwig J, Usadel $\mathrm{KH}$, Badenhoop K. CTLA4 alanine-17 confers genetic susceptibility to graves' disease and to type 1 diabetes mellitus. J Clin Endocrinol Metab. 1997;82(1): 143-6. https://doi.org/10.1210/jcem.82.1.3699.

134. Yanagawa $T$, Taniyama M, Enomoto $S$, Gomi K, Maruyama $H$, Ban Y, et al. CTLA4 gene polymorphism confers susceptibility to graves' disease in Japanese. Thyroid. 1997;7:843-6.

135. Villanueva RB, Inzerillo AM, Tomer Y, Barbesino G, Meltzer M, Concepcion ES, et al. Limited genetic susceptibility to severe graves' ophthalmopathy: no role for ctla-4 and evidence for an environmental etiology. Thyroid. 2000;10:791-8.

136. Koenecke C, Czeloth N, Bubke A, Schmitz S, Kissenpfennig A, Malissen B, et al. Alloantigenspecific de novo-induced Foxp3+ Treg revert in vivo and do not protect from experimental GVHD. Eur J Immunol. 2009:39:3091-6.

137. Kondo M. Lymphoid and myeloid lineage commitment in multipotent hematopoietic progenitors. Immunol Rev. 2010;238:37-46

138. Kristensen B, Hegedüs L, Lundy SK, Brimnes MK, Smith TJ, Nielsen CH. Characterization of regulatory B cells in graves' disease and Hashimoto's thyroiditis. PLoS One. 2015;10(5):e0127949. https://doi.org/10.1371/journal. pone. 0127949.

139. Kambayashi T, Laufer TM. Atypical MHC class II-expressing antigenpresenting cells: can anything replace a dendritic cell? Nat Rev Immunol. 2014;14:719-30

140. Kristensen B. Regulatory B and T cell responses in patients with autoimmune thyroid disease and healthy controls. Dan Med J. 2016;63(2):B5177.

141. Nagayama Y. Graves' animal models of graves' hyperthyroidism. Thyroid. 2007;17:981-8

142. Kuklina EM, Smirnova EN, Nekrasova IV, Balashova TS. Role of B cells in presentation of autoantigens to CD4(+) T cells in patients with autoimmune thyroiditis. Dokl Biol Sci. 2015;464:263-6.

143. Rosser EC, Mauri C. Regulatory B cells: origin, phenotype, and function. Immunity. 2015:42:607-12.

144. Hong SH, Braley-Mullen H. Follicular B cells in thyroids of mice with spontaneous autoimmune thyroiditis contribute to disease pathogenesis and are targets of anti-CD20 antibody therapy. J Immunol. 2014;192:897-905.

145. Salvi M. Immunotherapy for graves' ophthalmopathy. Curr Opin Endocrinol Diabetes Obes. 2014:21:409-14. 
146. Maravillas-Montero $J L$, Acevedo-Ochoa E. Human B regulatory cells: the new players in autoimmune disease. Rev Investig Clin. 2017;69:243-6.

147. Miyagaki T, Fujimoto M, Sato S. Regulatory B cells in human inflammatory and autoimmune diseases: from mouse models to clinical research. Int Immunol. 2015;27:495-504.

148. Ray A, Dittel BN. Mechanisms of regulatory B cell function in autoimmune and inflammatory diseases beyond IL-10. J Clin Med. 2017;6:12.

149. Bossowski A, Grubczak K, Singh P, Radzikowska U, Dabrowska M, Sawicka B, Bossowska A, Moniuszko M. Analysis of $B$ regulatory cells with phenotype CD19+CD24hiCD27+IL-10+ and CD19+IL-10+ in the peripheral blood of children with graves' disease and Hashimoto's thyroiditis. Pediatr Endocrinol. 2015;14(Suppl 1):40. https://doi.org/10.18544/EP-02.14.01.1552.

Submit your next manuscript to BioMed Central and we will help you at every step:

- We accept pre-submission inquiries

- Our selector tool helps you to find the most relevant journal

- We provide round the clock customer support

- Convenient online submission

- Thorough peer review

- Inclusion in PubMed and all major indexing services

- Maximum visibility for your research

Submit your manuscript at www.biomedcentral.com/submit 